\title{
$\underline{\mathrm{Nb} \text { paras 2-3 cut from PCLW3 and may need restoring }}$
}

\section{Time Bandits: Temporality and the Politics of Form in Palestinian Women's Life-Writing}

\section{Bart Moore-Gilbert}

\section{Introduction}

1. In seeking to admit Palestine ${ }^{1}$ as an appropriate and legitimate object of study within Postcolonial Cultural Sudies, strategic claims are likely to continue for some time to revolve around what the region has in common in respect of its history and experiences with other parts of the (formerly) colonised world habitually engaged by the sub-field; and around what parallels Palestinian cultural production offers with that of other (post)colonial formations and traditions in terms of mediating resistance to foreign hegemony and advancing the goals of national liberation. Crucial though they undoubtedly are, it would be regrettable if these thematic / political preoccupations entailed the neglect of aesthetic issues, which should not be neglected by any form of Postcolonial Cultural Studies worthy of the name. ${ }^{2}$ However, I am not proposing to divorce inquiry into aesthetic matters from broader and more obviously material issues of politics and history, but rather to reinforce the link between the two. As Fredric Jameson argued more than thirty years ago, aesthetic form expresses the 'political unconscious' of cultural texts. One of the critic's duties, therefore, is to read its characteristics symptomatically, in terms of clues they may offer about the work in question's relation to social reality and the structural forces which determine that reality. Indeed - and this seems particularly important in relation to the ongoing colonial predicament of Palestine - such an approach may 'restore our sense of the concrete situation in which such forms can be seized as original and meaningful protopolitical acts.' (Jameson 149) Moreover, as I shall attempt to demonstrate, it may direct attention to important themes in Palestinian culture which might otherwise be overlooked. $^{3}$

4. My argument will be pursued through examination of some formal characteristics of one particular genre, autobiographical life-writing. In 1990 Salma K. Jayyusi commented on its significant role within Palestinian cultural production:

One of the most interesting phenomena about Palestinian literature today is the abundance of personal account literature. This must stem from the experience of uprootedness, from the fact that a good part of the present world tries to dislodge the Palestinians and to deny the tragic facts of their recent experience. (Jayyusi vii)

This role has expanded in the near quarter-century since Jayyusi's intervention, with the appearance of many more such works which continue to 'stand in defence of this society's integrity against the forces that try to smash and disintegrate it' (ibid). Moreover, the sheer literary excellence of several of these has brought Palestine to the attention of the global audience for life-writing - as well as of general readers - who might not otherwise be interested in the region. Such works include Mourid Barghouti's I saw Ramallah (1997); Edward Said's Out of Place (1999); Ghada Karmi's In Search of Fatima: a Palestinian Story (2002); Raja Shehadeh's Strangers in the House (2002) and Palestinian Walks: Notes on a Vanishing Landscape (2007); and Suad Amiry's Sharon and My Mother-in-Law: Ramallah Diaries (2003/04. All 
these texts, with the exception of Barghouti's, attest to another extremely significant development since Jayyusi's pronouncements, a development which is evident in Palestinian cultural production more broadly and should further encourage engagements from within Postcolonial Cultural Studies in the Anglophone world. This is the proliferation of work - fiction, film, drama, as well as life-writing - in the medium of English, which is increasingly being produced not only in the diaspora but by Palestinians located within the borders of former Mandate Palestine.

5. Increasingly prominent, within both the expanding field of Palestinian cultural production and of life-writing more specifically, are Palestinian women. Like their male counter-parts, these women writers certainly employ the genres of life-writing in part because of their suitability as testimonio, to witness to the seemingly endless cycles of colonial dispossession and oppression suffered by Palestinians and the ofen terrible price thereby exacted on their everyday lives. However, unlike most of their male colleagues - and complicating the claims of nationalism to include equally all those it claims to speak on behalf of - these women life-writers also consistently provide a critique of the patriarchy of many forms of Palestinian political organisation and mobilisation (an issue which has parallels in most other (post)colonial regions and histories).

6. In the case of Palestine, the roots of such critique can be traced back at least as far as the 1930s, which witnessed the emergence of armed struggle against the British Mandate authorities. In Fadwa Tuqan's A Mountainous Journey (1985), for example, the writer remembers her younger self questioning the legitimacy of family demands made, at the outset of her writing career during the Arab Revolt, to produce 'nationalist poetry.' Tuqan's scepticism was based primarily on the grounds that the gender norms enforced by the majority of her male (and female) relatives denied her access to the very forms of public engagement and experience which might make such poetry credible and convincing:

How and with what right does Father ask me to compose political poetry, when I am shut up in these walls? I don't sit with the men, I don't listen to their heated discussions, nor do I participate in the turmoil of life on the outside. I'm still not acquainted with the face of my own country, since I am not allowed to travel. (Tuqan 107)

Writing more than half-a-century on from the period Tuqan describes, Suad Amiry identifies continuing deep shortcomings in the gender politics of Palestinian nationalism, evidenced in her biting depiction of an International Women's Day rally in Ramallah:

It is the one day when it is difficult to define who the enemy is.

It is also the one day when Palestinian men see Israeli soldiers beat up and shoot at Palestinian women but won't do much about it. (Amiry 92-3)

Thus Palestinian women's life-writing attests repeatedly to what Tuqan calls the 'double struggle' facing her gender, one alongside her men-folk in the quest for national freedom, the other against them in order 'to assert her liberation as a woman.' (Tuqan 204) ${ }^{4}$

7. The writers selected for analysis here - Leila Khaled, Fadwa Tuqan, Hanan Ashrawi, Ghada Karmi and Suad Amiry - comprise a group of diversely-located Palestinian woman life-writers of sometimes contrasting class origin, generation, religious orientation, political / ideological affiliation and language of composition. 
(With the exception of Tuqan, however, all their works were first published in English. ${ }^{5}$ ) Nonetheless, while one must bear in mind the sometimes important material differences between them - not least to prevent any temptation to essentialise Palestinian (life-)writing or identity, female or male - they share to different degrees an innovative approach to many of the conventions of autobiographical life-writing, as understood in the West at least. This extends to those identified as being characteristic of the revisionist modes of Western women's life-writing by feminist critics since the 1980s. ${ }^{6}$ Even when its Palestinian women's equivalents ostensibly share some of the formally experimental characteristics of such work, very different significance can often be attached to them.

8. This should be little surprise given the often radically contrasting 'concrete situation[s]' (Jameson 149) in which Palestinian women and their Western 'sisters' find themselves. As Khaled acknowledges, women in the 'First World' certainly have to confront both gender and class oppression. But, she goes on: 'I had to face four kinds of oppression: national, social (the weight of traditions and habits), class and sexual.' (Khaled 58) This evidently ignores the powerful role ethnicity (which is, however, perhaps included in the writer's conception of the 'national') can also play in both the identity of women and their oppression in the West. Nonetheless, her comments offer a starting point for investigating how material differences of history and cultural tradition often make the aesthetics of Palestinian women's life-writing signify 'otherwise' than in both mainstream and feminist / revisionist modes of Western life-writing. (They also suggest why one should resist seeing it as some 'universal' or trans-national expression of 'feminist' sentiment.) Given constraints of space, I confine myself to just two aspects of form which, in Jameson's phrase, 'can be seized as original and meaningful protopolitical acts.' (Jameson 149) More specifically, I explore how what Julie Peteet calls the 'overwhelmingly raw power of external forces' (Peteet 210) operating on Palestinian women - whether constituted by foreign Occupation or Palestinian patriarchy - can be traced as clearly in these aesthetic characteristics of their work as in its thematic content. [1394]

\section{non- / anti-linearity and the times of patriarchy and colonialism}

9. The first of these aspects of form concerns non- / anti-linearity of narrative structure and development. In mainstream (male) Western Autobiography Studies the importance of orderly narrative structure is generally assumed, as in Philippe Lejeune's influential pronouncement that autobiography is 'a retrospective prose narrative produced by a real person concerning his own existence, focusing on his individual life, in particular on the development of his personality.' (Lejeune 192) This implicit emphasis on temporally coherent and logical narrative structure began to be contradicted by feminist critics in the 1980s. Estelle Jelinek, for example, argues that the qualities of 'harmony and orderliness [and] unidirectionality' traditionally deemed crucial to securing the identity of the genre instead 'betoken a faith in the continuity of...[male] self-images.' Conversely, Jelinek goes on, women's life-writing is much more likely to be 'disconnected, fragmentary, or organised into self-contained units.' (Jelinek 17) In part, she suggests, this comprises an aesthetic choice about which narrative structures best reflect the life-experiences and self-images of women; but it has a further important cultural/ political dimension insofar as it often constitutes a self-conscious rejection of aesthetic norms underpinning the patriarchal authority of male writers and critics. As will be seen, such experiments have 
significant implications not just for the temporalities characteristic of male lifewriting but Lejeune's conception of trajectories of formation of Selfhood and identity as well.

10. Its important not to exaggerate the non /anti-linearity of Palestinian women's life-writing. Even writing which is obviously experimental at the level of structure, like Tuqan and Amiry's, never entirely disavows chronology or linearity in relation to narrativising the protagonist's development. Nonetheless Palestinian it often conforms to the patterns which feminist critics have identified in the revisionist modes of western women's autobiographical writing, patterns which have equally powerful implications for autobiographical temporality and its relationship to Selfhood. Thus it could be argued that a fundamental division, even fracture, characterises Tuqan's $A$ Mountainous Journey, preventing it from cohering into any aesthetic whole as conventionally understood. The text is organised into a first part comprised of 33 numbered, seemingly autobiographical segments, followed by a second part comprised of 27 diary excerpts. Moreover, syntactic continuity is not necessarily a prime objective whether between or within the sequence of segments offered. Thus the transitions of focus in segment 12 of the first part of A Mountainous Journey, to take a random example, might seem abrupt, if not arbitrary. Temporally it jumps from 1929 to 1955 and back again and, thematically, from meditation on Tuqan's early bent for poetry to reflection on a passage from the Old Testament to discussion of the part played by chance in life and a description of her first reading at the University of Beirut. The disjunctive nature of this section is reinforced by the fact that here (as in other segments), the prose narrative is interrupted by the inclusion of two poems, only one of these, furthermore, being a partly autobiographical piece by / about Tuqan herself. At the macrological level, there is a similar pattern of recursivity, partly as a consequence of Tuqan's lack of concern with strict chronology, partly because of the dialectic between ideas and situations of of imprisonment and freedom.

11. This fragmentary, recursive, genre-hopping and paratactic style supports Fedwa Malti-Douglas's claim that A Mountainous Journey constitutes 'an attack on the traditional autobiographical form itself.' (Malti-Douglas 3) As with some Western women's life-writing, such experimentalism can credibly be linked to a programmatic contestation of patriarchy, a pattern evident in Tuqan's earlier experimentation in poetic convention. This can certainly be understood to be as much a gendered dynamic as aesthetic in provenance, a dynamic which plays itself out in her relationship with her brother Ibrahim, himself a leading Palestinian poet of the 1930s. Ibrahim undoubtedly plays a key role in Tuqan's development as a poet - not least by introducing her to an inspirational tradition of classical Arabic women's poetry. However, he is also strikingly, if unwittingly, patriarchal in the way that he organises and directs his sister's programme of study and practice. Tuqan's eventual rebellion against Ibrahim's prescriptions, enthralled as they are to the conventions of classical Arabic verse, is partly reflected in her increasing recourse to contemporary Arab women writers, in search of more enabling templates for her own work. Thus $A$ Mountainous Journey reprints an early Tuqan poem, addressed to the emerging Egyptian-born Iraqi poet of the 1930s, Rabab al-Kazimi, which ends with the lines 'Oh poets / Do not stand in the way of women poets!' (Tuqan 61) During the 1930s, the text also informs us, Tuqan was particularly interested in the work of Mai Ziade (1886-1941), the Nazareth-born proto-feminist, translator, poet and confidant of Khalil Gibran. 
12. Perhaps most important in relation to the new directions taken in Tuqan's poetry, however, was Nazik al-Malaika, another poet of Iraqi origin. Her 1949 collection, Shawaza wa ramad (Shrapnel and Ashes) was, according to Ferial Ghazoul (184), remarkable not just for its poems but for an introduction widely interpreted as being a manifesto for new kinds of free verse. Tuqan refers to alMalaika more than once as 'an avant-garde poetess,' and argues that she 'is to be credited for her pioneering role in the evolution of form in contemporary Arabic poetry.' (Tuqan 71) By defying Ibrahim in the search for more appropriate templates and in choosing 'freedom from the bonds of ancient prosody' (Tuqan 75), then, Tuqan also symbolically liberated herself from social-literary institutions hitherto largely constructed and policed by men. In doing so, she not only achieved her own distinctive style but what Salma K Jayyusi describes as a hitherto unexampled 'liberation of the erotic' (Jayyusi x) in Arab women's poetry. Further, she constructed a new poetic oeuvre which was decidedly and ground-breakingly 'confessional' in character. Arguably, A Mountainous Journey represents a reiteration of these aspects of Tuqan's earlier aesthetic in the prose autobiographical mode. This helps, in particular, to explain not only the number of poems it contains and the highly poetic texture of her language and imagery, but the quasi-Modernist structure of the narrative, albeit a quasi-Modernism derived in the first instance from local and regional sources rather than from the West.

13. Such formal experimentation as Tuqan's bears a close relationship to issues of temporality, particularly of autobiographical kinds. For Tuqan the baleful effects of Palestinian patriarchy inhibit the experience of temporality necessary to enact any orderly trajectory towards the achievement of the kind of resolved Selfhood commonly associated, in the West at least, with autobiography. This idea is announced from the beginning of the text where the author complains of 'the timeworn rules difficult to overturn...I yearned continually to escape from my time and place.' (Tuqan 12) Her sensation of being 'buried alive' (Tuqan 36), her recurrent nightmares about being chased by an angry old man and her constant construction of her home as a prison all testify to the sense of temporal stasis associated with patriarchy. Conversely, her periods of escape from such confinement are strongly associated with the forward movement of time, even if such interludes are in themselves stop-start by nature and often conclude by returning her to the stasis of tradition. Thus Tuqan's brother Ibrahim, who is so instrumental in her development as a poet is represented as someone 'fifty years ahead of his time' and 'a bridge over which I could pass from one stage to another' (Tuqan 57) If Jerusalem represents a liberatory site for personal and artistic development, which is characterised by rapid development towards a Modernity which potentially includeswomen, it is only in the more developed Modernity of England that she comes to fully understand, define and experience the temporality she truly cherishes, namely that 'every minute one is reborn, leaving behind a personality different from the present one.' (Tuqan 180) [1300]

14. Amiry's Sharon offers many points of comparison with Tuqan's text in terms of its form. It, too, has a two-part structure, the relative independence of each part being signalled by the fact that the second was composed first and published separately as a stand-alone piece. Each half of the book is further sub-divided into short segments, some of which are further sub-divided in turn. While the author 
comments that the text was reordered chronologically for the English edition (Amiry $\mathrm{x}$ ), linear chronology is never an over-riding structuring principle. Section 1 of Part One is dated fourteen years later than Section 2 and Section 9 contains material from a period earlier than Section 8. Even within particular sections, there are abrupt temporal transitions, introduced by phrases such as 'Three years later, the phone rang' or 'Years later, the phone rang.' (Amiry 33, 52) In turn, syntactic continuity between Sections does not seem the highest priority at the semantic level. For example, there is no obvious connection in Part Two of Sharon and My Mother-in-Law between the sub-sections entitled 'Capuccino in Ramallah' and 'Our New Neighbours' - beyond Amiry's over-arching concern to provide snap-shots of (her and others' responses to) different aspects of life under Occupation. In this instance as in many others, meaning does not derive from spatial or temporal alignment but from thematic or tropic contiguities. Thus many of Sharon's segments could be shuffled into a different order without diminishing its overall effect.

15. However, such experimentation with the linear narrative structures conventionally associated with autobiographical modes of life-writing cannot always be said to derive simply, or even primarily, from the gender concerns of the writers in question. Not only would such a claim would risk essentialism, but perhaps more importantly, it would ignore the obvious role played by the wider socio-political contexts, or 'concrete situation' (Jameson 149) within which their work emerges and operates. In particular, the seemingly fragmented, paratactic, recursive quality of some Palestinian women's life-writing clearly draws attention to the effects of colonial hegemony on the experience of temporality amongst the colonised.

16. The structure of Amiry's work reflects quite obviously the temporal disruptiveness of foreign Occupation. Thus at different moments the passage of time seemingly stretches unbearably, as in Amiry's allusion to 'seven years of continuous agony over my residency' (Amiry 34) or the long dark winter months of exile in Scotland, or the hours spent at check-points, or the seemingly interminable periods of curfew in Ramallah, amounting on one occasion to forty-two days (Amiry 130) During such deadly periods of curfew, time drags so heavily that 'utterly bored' (Amiry 180), there is nothing for Amiry to do but to turn to the 'little death' of sleep. Equally curfews, often imposed or suspended with Kafkaesque arbitrariness, enforce a stop-start repetitiveness in Palestinian life which seems to freeze time, similarly inhibit the possibility of temporality unfolding in the conventional linear fashion assumed in mainstream western autobiographical writing. As Salim comments after yet another night broken by the noise of Israeli incursions: "Nothing changes." (Amiry 120) Waiting, whether for permits, gas-masks, or curfews to end, is one of the most common (in)activities - and words - in Amiry's text, requiring the perfection of mental disciplines to 'step out of the [time-]frame' (Amiry xi) in order to survive psychologically. Conversely, one striking aspect of the trip to the Sinai peninsular at the end of the text is how Amiry's time once more becomes her own and operates normally again. It is not just being able to move about freely - unlike in the Occupied Territories - but being able 'to stay out late at night' (Amiry 185) which so impresses and delights her. Thus the abrupt jumps and gaps or blanks in Amiry's texts can be understood on one level as the formal analogue of the gaps and blanks which ensue from the disruptions of Palestinian temporality under Occupation, experience of which is inimical to the linear narrativisation of life-stories organised from a stable 
vantage point where past events can be easily understood in their relation to the present.

17. Even in less obviously formally experimental writers, however, the theft of Palestinian time and, more specifically, the deformations of temporality ensuing on colonial subjection weigh heavily. Thus for Hanan Ashrawi, Palestinian history, in which her own individual being is so heavily implicated through her role as witness to the depredations of Israeli hegemony, is an 'endless cycle,' which repeats its 'substance ad nauseam in various forms' (Ashrawi 41, 250) Consequently, even the ostensibly straightforwardly linear, memoir elements of her text often have a strongly recursive feel, the constant stalling on the Israeli side making it almost impossible at times to distinguish between the different stages of political negotiation in which she and her delegation are involved. At one point, she invokes the recursive structure and static temporality of the One Thousand and One Nights to describe the endless return to the same point in negotiations (Ashrawi: 182). Little wonder that she describes the Madrid negotiations as a 'circular penitential journey,' the eventually disappointing outcomes of which bring her side 'full circle.' (Ashrawi 187, 302) For Ghada Karmi, by contrast, the enduring trauma of colonial dispossession continues to deny full continuity of personal temporality in diaspora, despite the essentially linear, 'realist' narrative development of her life-history. Her memories of childhood, for example, remain punctured by blanks and absences as well as a lack of material evidence in the form of photographs. These discontinuities are caused mainly by the necessary blotting out of the anguish of her family's flight from Qatamon during the panic created by the massacre at Deir Yassin by Zionist militia. In her mother's case, the effects of such trauma on the individual experience of temporality in diaspora are even more radical: 'Like some Palestinian Miss Havisham, for her, the clock stopped in Jerusalem in April 1948.' (Karmi 174) [984 / 2288]

\section{Inter-genericity and temporality}

18. The second aspect of form on which I want to comment in relation to Palestinian women's life-writing also has profound implications for temporality, including the temporalities conventionally associated with autobiographical modes. This aspect of form one might label inter-genericity, or traffic across / between (sub-) genres. Male critics, according to their Western feminist Autobiography Studies colleagues, have proved generally keen to secure the established borders of lifewriting genres against contamination by others; and it is certainly true that much of the voluminous historical efforts from Georg Misch onwards to define them can be understood as forms of border policing (Marcus 229ff). By contrast, as Shari Benstock, for example, puts it: 'Writing that that works the borders of definitional boundaries bears witness both to repressive inscription under the [patriarchal] law of genre and to the freedom and dispossession of existence outside the law.' (Benstock 2) Such critics extrapolate their arguments from Western women's life-writing, particularly its feminist varieties, which they consider to be often characterised by a more or less promiscuous mixing of life-writing with other genres normally kept apart in mainstream male life-writing.

19. There are elements of such kinds of inter-generic experimentalism in Palestinian women's life-writing. For example, Tuqan writes copiously about 1930s Palestinian history as the context within which she was formed as an adolescent / 
young adult as well as reproducing substantial amounts of poetry within her work. Hints at deployment of conventions of fiction occur in Ghada Karmi's text, as implied in the sub-title A Palestinian Story and her narrative often reads like a novel. But in Palestinian women's life-writing, inter-genericity is evident less in relation to the external borders but within, along the borders of the various sub-genres which constitute life-writing itself. Thus it often segues - more or less abruptly - between sub-genres of life-writing as diverse as autobiography, biography, testimonio, memoir and journal/ diary, the latter two modes being particularly significant in regard to issues relating to both autobiographical temporality as conventionally understood and, more specifically, Palestininian women’s experience of temporality.

20. For example, Amiry's work is sub-titled Ramallah Diaries and in the preface she describes the work as her 'presonal war diaries' (Amiry ix). The striking formal difference between the first and second parts of Tuqan's text is signalled in the latter's sub-title, 'Pages from a Diary 1966-1967.' And the final chapter of Karmi's text offers a no less striking formal contrast to what precedes, being a journal/ diary describing her return to Israel / Palestine for a two-week trip in 1991, more than forty years after expulsion from Qatamon. One inference to be drawn from the prominent role of these two sub-genres in such work is that, in Tuqan's case, the historical traumas consequent upon conquest, dispossession and Occupation remain too raw and overwhelmingly present to be fully containable within the retrospective vision of autobiography and memoir 'proper,' as defined by critics like Lejeune. Conversely, one might infer that the rupture between past and present, for example in the example of Karmi, is so profound as to make it equally impossible to suture them within a conventional retrospective autobiographical narrative. In turn, one might suggest that in Amiry's case the present is itself too raw and overwhelming to be able to be given any more distance and shape than is available in the relatively free, unstructured forms of the journal/ diary.

21. Conversely, conventional assumptions underlying the use of diarisitic forms are also brought into question by the fact that the future occupies a much more important role in Palestinian women's life-writing than is generally the case in its Western equivalents. Autobiographical modes are generally understood to provide a summa of the protagonist's life, written towards the end of that life or at the end of a particularly significant segment of it; equally, they generally assume there will be no further major developments which might render the account in question obsolete or incomplete. By contrast, there is often a fundamental irresolution or incompleteness in Palestinian women's life-writing. To some extent this is a function of the use of the diary / journal modes which by definition do not begin from a vantage point which offers strategic finality or closure; nor do they progress teleologically towards such a vantage point.

22. But even work in more ostensibly conventional autobiographical or memoir modes often invokes the future as the only temporality within which narrative closure and personal resolution might potentially be found. Khaled, for example, begins her text with an epigraph by Ghassan Kanafani, the Palestinian writer probably murdered by Israeli agents in 1972: "WWe must love and be future-oriented if we wish to carry out the revolution."' (Khaled n.p., my emphasis) Her personal narrative (sub-titled 'the autobiography of a revolutionary' must thereby inevitably remain incomplete until the fulfilment of her dream to 'recover Palestine' and make it 'a human paradise 
for Arabs and Jews and all lovers of freedom. (Khaled 22) Ashrawi's work evinces a comparable sense of inconclusion and future-orientation: 'My personal narrative is [still] unfolding,' she comments at the end of This Side of Peace, which she offers as a pledge to her people's realisation of 'the full potential of a joy yet to come.' (Ashrawi 302-3) Such evidence reinforces the strongly representative dimension of these writers' work, implied in several of the titles / sub-titles (My People Shall Live, A Palestinian Story, Ramallah Diaries), the sense that their personal histories are synecdoches for Palestine's history. To this extent it suggests that there can be no personal closure while future of Palestine remains in doubt, in strong contrast to the more conventional focus on, and distinction between, the past-present relationship in Western life-writing. ${ }^{7}$

23. However, the distinction between tenses normally operative in autobiographical writing is further blurred in important ways in the texts under consideration, whether drawing on diaristic forms or otherwise, notably through deployment of the motif of 'return.' This idea is often introduced in the texts, implicitly or explicitly, as an ever-present concern, yet also as something to be deferred indefinitely into the future, to be effected when the time is right. Yet the very idea of return also obviously suggests a doubling back to something in the past, a recursiveness which confounds the conventional difference between these various tenses. Given the histories of Palestinian dispossession, removal and exile, several of the texts in question are understandably obsessed with this thematic, which is as much temporal as spatial in nature. Thus once she understands the reasons for her family's expulsion, 'return' becomes the organising principle of Khaled's life. On joining the Popular Front for the Liberation of Palestine, for example, she feels a liberating sense at last that 'I was on the road [back] to Haifa.' (Khaled 112) Prevented from getting there by her enforced refugee status in various neighbouring Arab countries, the strength of Khaled's attachment to 'return' is later figured in the seemingly reckless decision to force the captain of an air-liner she has hi-jacked to fly low over Haifa. At last - after decades away - she can once more see her city of origin.

24. The trope of 'return' is represented in less dramatic, but no less telling, fashion by later authors in relation to the stolen ancestral home. For example, Karmi's narrative trajectory climaxes with her visit as a tourist to the family house in Qatamon, nearly half-a-century after her family’s forced departure. Rather than providing any conventional autobiographical closure, however, the occasion crystallises more poignantly than ever her sense of alienation, and thereby the continuing grip of the past on the present, and the rupture between them, which runs through her text. In Amiry, the motif of 'return' occurs towards the beginning, rather than end, of her text. The long-anticipated visit to her parents' former dwelling in Jaffa is aborted at the last minute, however, when the author realises that its effects might be disastrous for her mental well-being - even though she herself was born in exile and has only others' memories of the house to call her own. Yet she is already aware that without making this visit, she cannot hope to achieve closure and begin a new life free of the hold of this aspect of the past, even as the future reaches towards her in the form of her guide and husband-to-be Salim. Consequently the 'unfulfilled search for my family house in Jaffa' (Amiry 173) continues to haunt her towards the end of the text.

25. The sometimes radical 'incompleteness' entailed by anti-linear structure, certain sub-generic choices and mixtures, the future gaze and the paradoxically 
inextricable / impossible imbrication of past and present in Palestinian women's lifewriting, all further represent clear challenges to conventional notions about the development and resolution of autobiographical Selfhood. As we have seen in the case of Lejeune, autobiographical modes are historically associated with ideas of orderly narrative development which track the Subject's trajectory towards completed Selfhood. This is attained in narrative terms by the eventual achievement of the narrator / protagonist's full understanding, in the present moment of writing, of how past events and experiences have enabled the protagonist's formation. However, feminist Autobiography critics like Mary Evans, for example, argue that (Western) women's life-writing challenges this aspect of 'the project of masculinity' which, she asserts, sees 'the completed self' as the goal of personal formation and autobiographical Selfhood (Evans 83). Instead, such commentators often claim, Western women life-writers view the willing embrace of heterogeneity and discontinuity of Self as more true to female experience and seek to represent this fact in their life-writing.

26. Here, too, however, we see important differences between Palestinian women's life-writing and its Western equivalents. Greater emphasis tends to be placed in the former work on the undesirable discontinuities of Selfhood imposed by 'the overwhelmingly raw power of external forces'. Thus Tuqan alludes early in her text to the 'dual psyche' (Tuqan 28) she had to develop in order to preserve herself from patriarchal subordination at home. So severe does the pressure become that she feels 'as if something had been broken inside...constricted and crushed' (Tuqan 111) and even attempts suicide to resolve her conflict. Amiry is equally emphatic about the ways in which colonial Occupation enforces undesirable modes of disjunctive Selfhood on the colonised. She writes eloquently of 'the mental and psychological barriers, checkpoints and separation walls I had personally built in and around myself and my life' (Amiry 189) in order to cope in daily life. The alarming inference to be drawn is that the Israeli infrastructure of oppression in the Palestinian Territories, represented most obviously by its physical architecture, begins to structure the inner worlds of the colonised, enforcing a psychic fragmentation which is paralleled in the cantonisation of what remains of their homeland. ${ }^{8}$

27. As has been seen earlier in with respect to Tuqan's treatment of the effects of patriarchy on Palestinian women, in some of these instances of decentred Selfhood, issues of temporality can also be a crucial factor, inhibiting the progressive development towards coherent Selfhood commonly identified as the goal of mainstream Western autobiographical life-writing. In Karmi's case, as a result of dispossession and exile, the author, no less than her mother, is forced to exist in two time-frames, that of Palestinian tradition and that of Western Modernity as represented by the England she grows up in from the age of eight. Karmi describes herself as progressively losing 'awareness of myself as Palestinian and [soon]I never gave the matter any thought.' (Karmi 365). Indeed, her early teenage years in diaspora are largely spent resisting her parents' efforts to remind her that she is Palestinian. In particular, she resists the 'backward' temporality associated with Palestinian tradition, more particularly still, her mother's conception of the gender behaviour appropriate to Palestinian girls, wherever they might find themselves. Instead, Karmi seeks to embrace the Modernity which London represents, a metropolis characterised by a vibrant emergent new youth culture which includes espresso bars, fashion and the Beatles, as well as the swiftly evolving new gender norms she associates with the 
mini-skirt. However, as she grows older, and particularly after the 1967 war, the Palestinian dimensions of Karmi's past assert themselves increasingly, engendering an ever-deepening inner conflict. In seeking to 'return to the source' represented by tradition, she develops a psychic fracture equivalent to Tuqan's. Thus what she describes as the disabling 'dilemma of my two selves' (Karmi 295), a dilemma which is never resolved even at the end of the narrative, can be understood to be as much a function of disjunctive temporalities as other dimensions of dislocation and exile, important though the latter factors undoubtedly are. [2099]

\section{Conclusion}

28. Much work remains to be done on the formal specificities of Palestinian women's life-writing and their relationship to the 'concrete situation' in which such authors find themselves. For example, further analysis is needed of its specific modes of hybridizing different genres and narrative templates - Palestinian, Arab and international; and of its pronounced use of varieties of humour to produce distinctive tonalities which advance it strategic aims. Yet I hope even my brief analysis of two aspects of the forms of Palestinian women's life-writing demonstrates the productivity of the kind of approach which Jameson recommended several decades ago now. Such an approach is not an escape from the 'concrete situation' from which such authors and texts emerge, but rather offers avenues to some of its most important thematics, thematics which are crucial in making Pal a legitimate object of study for Postcolonial Cultural Studies. The theft of Palestinian land and resources and the displacement of its peoples will likely and understandably seize most attention in attempts to admit 'Palestine' as a legitimate area of inquiry in Postcolonial Cultural Studies. However, an approach which is attentive to issues of aesthetics can supplement such foci with the suggestion that the theft of Palestinian time (and history) is an equally grave and deleterious consequence of colonial regimes under which so many Palestinians have suffered - whether those who remain within the borders of former Mandate Palestine or in the often far-flung diaspora.

29. Moreover, critical attention to issues of form will help further clarify the distinctiveness of Palestinian women's contributions to the sub-genres of life-writing as understood in the West, at least. All the texts under consideration are written by women well-versed in Western literature. Ashrawi, for example, was head of the Department of English at Birzeit University, specialising in British medieval literature - which she cites from time to time in This Side of Peace. Tuqan cites writers as varied as Goethe and T.S. Eliot and she also studied English literature at summer schools in Oxford. Meanwhile Amiry, another university lecturer, mentions western writers as diverse as Kafka and Tracy Chevalier amongst the writers she is familiar with. By the age of twelve, Karmi tells us, she was an avid reader of English literature, with Dickens apparently a particular favourite. Even Khaled found time to study English, together with Arabic, literature at the American University in Beirut before becoming a revolutionary. Yet strikingly absent from any of the texts under consideration is any reference to Western autobiographical traditions. When autobiographical genres are invoked, such citations are exclusively to works from the Arabic heritage. Thus Tuqan references a range of such work, from al-Ghazzali in the medieval period to her Egyptian near contemporary Taha Hussein. Amiry, by contrast, alludes to the work of the Moroccan Fatema Mernissi (who, like Amiry, wrote her text in English) and Raja Shehadeh, friend and fellow-inhabitant of Ramallah. Such 
evidence suggests these writers' desire not only to achieve independence from traditional patriarchy and foreign rule but to establish independent modes of articulating what is specific to Palestinian women's experience. [511]

\section{Bibliography}

Amiry, Suad. Sharon and my Mother-in-Law: Ramallah Diaries (2003-04; London: Granta, 2005).

Ashrawi, Hanan. This Side of Peace: a Personal Account (New York: Simon and Schuster, 1995).

Benstock, Shari. 'Introduction' to Benstock, ed., The Private Self: Theory and Practice of Women's Autobiographical Writings (London: U. North Carolina P., 1988): 1-6.

Evans, Mary. Missing Persons: the Impossibility of Auto/biography (London: Routledge, 1999).

Ghazoul, Ferial. 'Iraq,' in Radwa Ashour, Ferial Ghazoul and Hasna Reda-Mekdashi, Arab Women Writers: A Critical Reference Guide, 1873-1999 (2004; American University in Cairo Press, 2008): 178-203

Gilmore, Leigh. Autobiographics: A Feminist Theory of Women's Self-Representation (Ithaca: Cornell U. P., 1994).

Hussein, Abdirahman. Edward Said: Criticism and Society (London: Verso, 2002).

Jameson, Fredric. The Political Unconscious: Narrative as a Socially Symbolic Act (London: Methuen, 1991).

Jelinek, Estelle, 'Introduction: Women's Autobiography and the Male Tradition' in Jelinek, ed. Women's Autobiography: Essays in Criticism (Bloomington: Indiana U.P., 1980): 1-20.

Jayyusi, Salma K. 'Foreword: Mistress of the Two Gifts: Love and Pain,' in Fadwa Tuqan, A Mountainous Journey: a Poet's Autobiography ed. Salma K Jayyusi, trans. Olive Kenny (1985; St Paul, Minnesota: Graywolf Press, 1990): vii-xiii.

Karmi, Ghada. In Search of Fatima: a Palestinian Story (London: Verso, 2002).

Khaled, Leila. My People Shall Live: the Autobiography of a Revolutionary ed. George Hajjar (London: Hodder, 1973).

Lejeune, Philippe. 'The Autobiographical Contract' trans. R. Carter, in Tzvetan Todorov, ed., French Literary Theory Today: a Reader (Cambridge: Cambridge U.P., 1982): 192-222.

Peteet, Julie. Gender in Crisis: Women and the Palestinian Resistance Movement (New York: Columbia U.P., 1991) 
Malti-Douglas, Fedwa. 'Introduction' to Fadwa Tuqan, A Mountainous Journey: a Poet's Autobiography ed. Salma K Jayyusi, trans. Olive Kenny (1985; St Paul, Minnesota: Graywolf Press, 1990): 1-9.

\author{
Marcus, Laura. Auto/biographical Discourses: Theory, Criticism, Practice \\ (Manchester: Manchester U. P., 1994).
}

Said, Edward. Orientalism: Western Conceptions of the Orient (1978; London: Penguin, 1991).

Smith, Sidonie. A Poetics of Women's Autobiography: Marginality and the Fiction of Self-Representation (Bloomington: Indiana U. P., 1987).

\author{
Spivak, Gayatri. A Critique of Postcolonial Reason: towards a History of the \\ Vanishing Present (Cambridge, Mass.: Harvard U.P., 1999).
}

Tuqan, Fadwa. A Mountainous Journey: a Poet’s Autobiography ed. Salma K Jayyusi, trans. Olive Kenny (1985; St Paul, Minnesota: Graywolf Press, 1990) [364]

\title{
$6675+401$ notes $=7076$
}

\footnotetext{
${ }^{1}$ The use of inverted commas around this term expresses my sense of its highly problematic epistemological status. No such place currently exists as a legally-recognised political / geographical entity and it is used to refer variously to the area formerly known as Mandate Palestine, the territories currently under the nominal control of the Palestinian Authority and a future state of unknown borders which might or might not be bi-national.

${ }^{2}$ Attention to the distinctive properties of the aesthetics of Palestinian cultural production, notably the range and specificity of the styles, forms and genres employed in resisting oppression and in imagining independent futures may, furthermore, offer some safeguard against the historical tendency of the subfield to homogenise its objects of analysis, certain accounts implying that some kind of equivalence exists between Canada, Wales, even the United States on the one hand and Tanzania, Tobago and Singapore on the other by virtue of the fact that they were all at one time subject to British rule. [EWB] Such congeries are problematic enough without throwing Palestine, with its many unique features as a (post)colony into the mix. (These include the absence of any territory uniformly recognised as Palestine, the variety of different kinds of foreign rule exercised over it during the last century and the fact that almost half of Palestinians live in exile).

${ }^{3}$ Paras 2-3 cut

${ }^{4}$ For a fuller analysis of the thematics, as opposed to the formal treatment, of this 'double struggle,' see my “'Baleful Postcoloniality” and Palestinian Women’s Life-Writing,' forthcoming, Biography: An Interdisciplinary Quarterly 36.1 (Winter 2013).

${ }^{5}$ Khaled's text represents another possible exception in the sense that her narrative was delivered orally to George Hajjar, presumably in Arabic, who then arranged and translated her reminiscences. Note, however, that Khaled spoke English at home while growing up in Lebanon. (108)

${ }^{6}$ For a fuller discussion of postcolonial life-writing in these regards, see my Postcolonial LifeWriting: Culture, Politics and Self-Representation (London: Routledge, 2009)

${ }^{7}$ This suggests that my argument about the theft of individual women's time could be generalised to consideration of the theft of Palestinian history, too. This latter has a material dimension, which there isn't space to address on the present occasion, represented by, for example, Karmi's father's forced abandonment of his library when the family leaves Qatamon or Amiry's visit to the bombed buildings of historic Nablus.

${ }^{8}$ For a sense of the psychological toll entailed by the Gaza blockade, for example, see http://www.guardian.co.uk/global-development/2012/jul/11/israeli-blockade-mental-health-gaza
} 